\title{
An Experimental Study of the Wave Number Selection for the Finite Amplitude Rayleigh Convection
}

\author{
By Yoshimitsu Ogura* and Hiroji Tsu \\ Ocean Research Institute, University of Tokyo, Nakano, Tokyo \\ (Manuscript received 16 March 1970)
}

\begin{abstract}
Laboratory experiments have been made to investigate the dependence of finite-amplitude Rayleigh convection cells on the initial conditions of the system. Controlled perturbations with prescribed width-depth ratios were introduced into the fluid (silicon oil) confined in a box which had a small breadth. Subsequent evolution and final steady flows at the Rayleigh number of approximately $45 R_{c}$ were observed, where $R_{c}$ is the critical Rayleigh number. It was found that "two-dimensional" convection cells showed tendencies to adjust their sizes toward the vicinities of the width-depth ratio of 2.3 , provided their initial width-depth ratios were outside the range between approximately 2 and 3 .
\end{abstract}

\section{Introduction}

When a layer of fluid is heated from below and cooled from above uniformly, and the temperature difference between the top and bottom of the fluid layer (or more generally, the Rayleigh number) exceeds a critical value, the familiar Bénard-Rayleigh convection takes place. The onset of such flows has been thoroughly studied theoretically and experimentally. However, the understanding of the finite-amplitude BénardRayleigh convection at supercritical conditions is not complete.

One of the questions to be answered concerns the manner in which modes are selected in steady-state finite-amplitude cellular convection. It is recognized that a steady-state solution to the non-linear equations of motion may not be determined uniquely by the steady-state boundary conditions. In other words, there may be a manifold of steady-state solutions for each point in parameter space. The question is then what modes can be expected to exist in finite-amplitude flow, whether the expected modes bear any relationship to the linear modes or not, and to what extent are the expected modes determined by the initial conditions or by the past history of the system.

* Present address: Laboratory for Atmospheric Research, University of Illinois at Urbana-Champaign, Illinois.
Several experimental investigations have been made to answer this question. The most relevant experiment to the present study was made by Chen and Whitehead (1968). Instead of initiating the convective motion in the fluid by heating uniformly from below, they introduced small controlled perturbations prior to the onset on motion and investigated the subsequent evolution of two-dimensional cellular convection cells. They concluded that two-dimensional cells with widthdepth ratios close to 2 are stable at all Rayleigh numbers investigated (less than 2.5 times the critical Rayleigh number) whereas cells whose width-depth ratios are moderately too large or too small tend to undergo size-adjustments toward a preferred value of about 2.2. Ogura and Yagihashi (1969 a and b) also demonstrated that the numerical steady solutions for two dimensional Rayleigh convection are not unique for fixed boundary conditions and slightly different initial conditions produce different finite-amplitude steady solutions. Related to this problem is the selection of modes in rotating Couette flows. Recently Snyder (1969) presented, with an excellent review on this problem, his experimental results which demonstrated the interval over which the wavenumbers of secondary periodic vortices in a rotating Couette flow can be varied for the fixed parameters of the system.

The purpose of this short paper is to present the result of our preliminary experiment which 
is similar to the Chen and Whitehead's experiment, but at much higher supercritical Rayleigh numbers and with a different geometrical configuration of the experimental apparatus: their working fluid was confined in a circular ring whereas we used a "two-dimensional" chamber.

\section{Experimental apparatus and procedure}

The apparatus used in the present experiments is shown in Fig. 1 where the convection chamber is $2.5 \mathrm{~cm}$ in height, $30 \mathrm{~cm}$ in width and $1.2 \mathrm{~cm}$ in breadth. The side walls were made of acrylic resin (the thermal conductivity: $0.5 \times 10^{-3} \mathrm{cal} \mathrm{cm}^{-1}$ $\mathrm{sec}^{-1{ }^{\circ}} \mathrm{C}^{-1}$ ) of $0.5 \mathrm{~cm}$ thick. In order to minimize the heat conduction through the side walls, they were covered by the styrofoam pads which were removed when visual observations were made. The top of the chamber was made of a brass plate of $0.1 \mathrm{~cm}$ thick whose temperature was controlled by a running water in a copper pipe $(0.8 \mathrm{~cm}$ in diameter) contacted with the top plate. A plate of mica of $0.15 \mathrm{~mm}$ thick was used for the bottom of the chamber. The thermal conductivity of this plate was $1.2 \times 10^{-3} \mathrm{cal}$ $\mathrm{cm}^{-1} \mathrm{sec}^{-1}{ }^{\circ} \mathrm{C}^{-1}$. The working fluid was silicon oil contaminated by aluminum powders for flow visualization. Physical constants of the silicon oil used in our experiments were as follows; the coefficient of viscosity $=1.0 \mathrm{~cm}^{2} \mathrm{sec}^{-1}$, the coefficient of thermal diffusivity $=1.05 \times 10^{-3} \mathrm{~cm}^{2} \mathrm{sec}^{-1}$, the coefficient of volume expansion $=8.8 \times 10^{-4}$ ${ }^{\circ} \mathrm{C}^{-1}$. The fluid was heated from below by an infrared radiation lamp which was placed $10 \mathrm{~cm}$ below the bottom of the chamber.

As described in the previous section, the purpose of the present experiment was to introduce controlled cellular perturbations with certain chosen modes into the fluid and then to observe the subsequent evolution of the flows subject to the uniform heating from below. The introduction of the controlled perturbations was performed by placing a wood plate (referred to as the grating hereafter) with a row of slits beneath the bottom of the chamber. The spacing between slits gives the mode of convection cells to be introduced.

The experimental procedure was as follows. The temperature at the top of the chamber and the voltage of the radiation lamp were maintained constant during the course of the experiment. The grating was placed beneath the bottom of the chamber. The infrared radiation passing through the slots heated the bottom of the fluid and excited the cellular convection with the prescribed mode. When the bottom temperature reached a quasi-steady state, the grating was removed. In most cases, it took about 90 minutes to reach this stage. The lamp continued to heat the fluid. Depending upon the chosen mode of starting perturbations, the mode-adjustment of the flow did or did not take place. In any case, the flow reached to the new steady state after approximately three hours. The flow pattern was photographed and the horizontal scale was measured. This procedure was then repeated ten times to check the diversity of the final steady state.

The temperature at the top and bottom of the fluid was measured by copper-constantan thermocouples with a diameter of $0.5 \mathrm{~mm}$ and continuously recorded by strip-chart recorders. Fig. 2 shows a typical example of the variation of the bottom temperature with time.

The choice of the mica plate for the bottom of the chamber was the result of a compromise

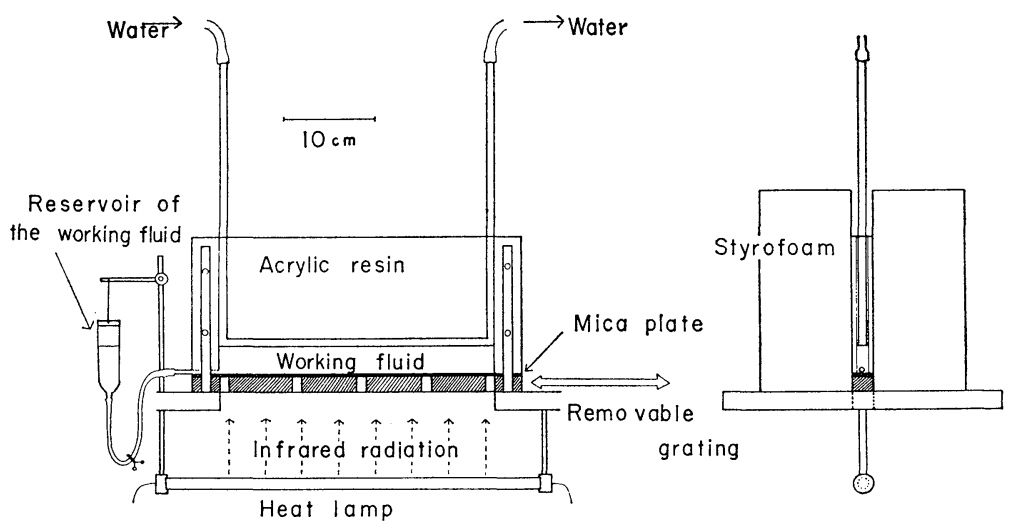

Fig. 1 Schematic diagram of the experimental apparatus. 


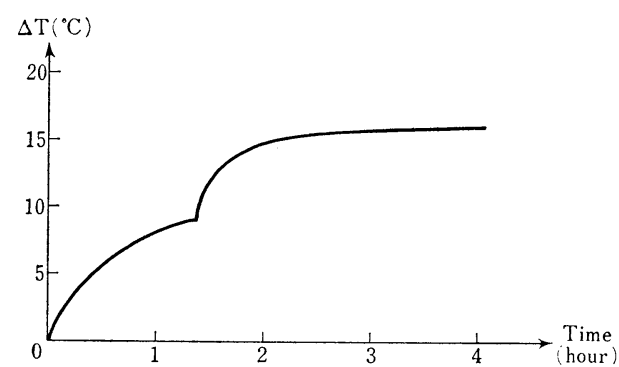

Fig. 2 A typical example of the time variation of the temperature difference between the top and bottom of the fluid.

of conflicting requirements. A plate with high thermal conductivity was desirable to attain uniform temperature distribution at the bottom, whereas it was undesirable for the purpose of introducing starting perturbations. The consequence of the poor conductivity of the bottom plate was that a horizontal temperature variation of less than $3^{\circ} \mathrm{C}$, approximately $10 \%$ of the vertical temperature difference, was observed even without the grating.

In measuring the modes of cellular convection from the photographs, cells at the ends of the fluid were ignored because these cells were considerably distorted by the influence of the sidewalls and the non-uniform horizontal temperature distribution mentioned above.

\section{Results and discussions}

According to the linear stability theory for Bénard-Rayleigh convection, the critical Rayleigh number is 1708 and the width-depth ratio of most preferred convection cells is 2.0 for rigid boundaries (Chandrasekhar, 1961). In our experiments, however, the critical Rayleigh number should be different from that cited above because of the presence of the side wall. Ukaji and Matsuno (1970) presented a simplified analysis to give approximate critical Rayleigh numbers in this situation, taking into account the influences of friction and heat conduction at the side-walls. According to their analysis, the critical Rayleigh number in our case is $5.2 \times 10^{3}$, about three times larger than that for the fluid of infinite horizontal dimensions. This critical value will be denoted as $R_{c}$ in the following discussion. Throughout this series of experiments, the temperature differences between the top and bottom of the fluid at the final steady state correspond approximately to $45 R_{c}$.

In the first phase of the experiment, convection cells were produced without placing any gratings. The mean width-depth ratio averaged over the 10 runs was found to be 2.3.

In the second phase, the experiment was performed following the procedure described in the previous section. The gratings of seven different slit spacing were used which gave the width-depth ratio of $6,4,3,2.4,2,1.5$, and 1.3 . Fig. 3 shows three examples of the undergoing of the initial modes to the final modes. Fig. 4 summarizes the result of the experiments. Each point in this figure indicates the average of 10 runs under the same condition and the horizontal line-segments indicate the standard deviations. It should be noted that the Rayleigh number at which the grating was removed was calculated using the temperature difference between the top and bottom of the fluid in the region of ascending motion.

We observed in Figs. 3 and 4 that cells with the width-depth ratios of $6,4,1.5$ and 1.3 are structurally unstable and tend to adjust themselves to have ratios in the range of 1.8 to 2.5 , whereas cells with the starting modes of $3,2.4$ and 2 keep

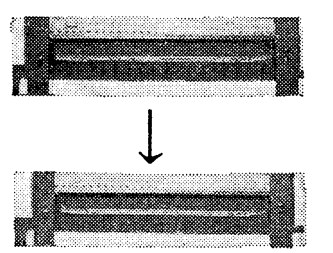

$\frac{\lambda}{h}=1.3$

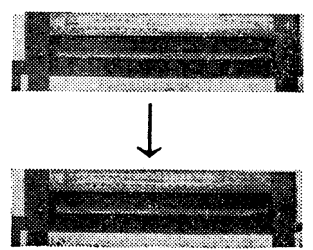

$\frac{\lambda}{h}=2$

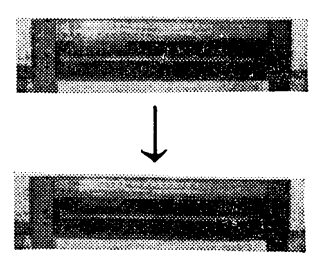

$\frac{\lambda}{h}=4$

Fig. 3 Three examples of the size-adjustment of convective cells toward the preferred modes. The upper photographs show the initial modes excited by the grating. The lower photographs show the final states. 


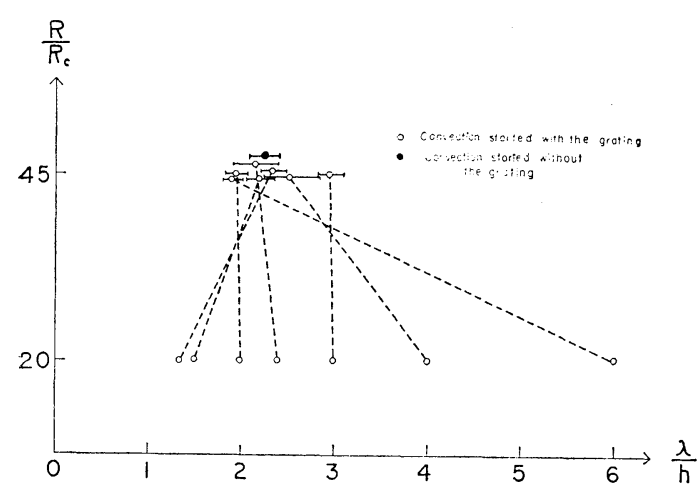

Fig. 4 Width-depth ratios of convective cells in the final states (upper points). Lower points show the initial width-depth ratios.

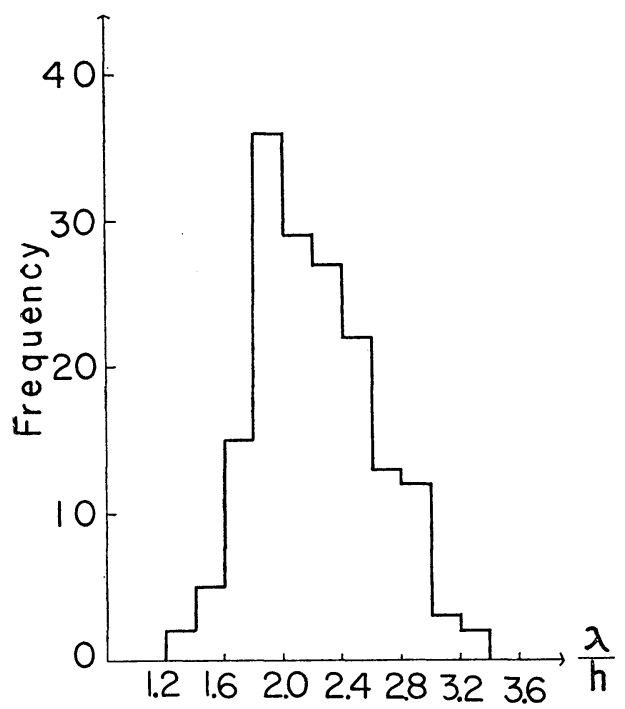

Fig. 5 Frequency distribution of final width-depth ratios of convective cells in the steady states.

their modes more or less unchanged. Fig. 5 shows the frequency distribution of the modes at the final states for the entire series of experiments. It appears that cells with the width-depth ratio in the range of 1.8 to 2.4 are most stable.

The result obtained above for fluid motion in a "two-dimensional" chamber indicates, in agreement with Chen and Whitehead's result, that convection cells are apparently stable provided their width-depth ratios are within a range in the neighborhood of 2, whereas cells would show tendencies to adjust sizes gradually toward the values in this range when the width-depth ratios are outside this range.

\section{Acknowledgments}

The authors wish to thank Mr. R. Kimura for his help in conducting this experimental study.

\section{References}

Chandrasekhar, S., 1961: Hydrodynamic and hydromagnetic stability. Oxford University Press.

Chen, M.M. and J.A. Whitehead, 1968: Evolution of two-dimensional periodic Rayleigh convection cells of arbitrary wave-numbers. $J$. Fluid Mech., 31, 1-15.

Ogura, Y. and A. Yagihashi, 1969a: A numerical study of convection rolls in a flow between horizontal parallel plates. J. Meteor. Soc. Japan, 47, $205-217$.

1969b: On the degeneracy of finite-amplitude steady-state solutions for Bénard convection in a highly truncated system. J. Meteor. Soc. Japan, 47, 437-445.

Snyder, H.A., 1969: Wave-number selection at finite amplitude in rotating Couette flow. J. Fluid Mech., 35, 273-298.

Ukaji, K. and T. Matsuno, 1970: Effect of lateral walls on the onset of convective motions. $J$. Meteor. Soc. Japan, 48, 217-223 


\title{
有限振巾のレーリー対流の卓越波数に関する実験
}

\author{
小倉義 光 - 津宏 治 \\ (東京大学海洋研究所)
}

レーリー数 $(R)$ が臨界值 $\left(R_{c}\right)$ より大きい場合, 外的条件は同一であっても有限振巾の定常対流七ルの縦横比は いつも同じとは限らない。その縦横比があらかじめ作った初期の擾乱のモードによってどの程度支配されるかを室内 実験により調べた，その結果（a）流体（シリコンオイル）を下部から一様に加熱した場合 $R=45 R_{c}$ においてセル の縦と横の比は 2.3 である.（b）初期の七ルの縦と横の比が 6, 1.5, 及び 1.3 の場合にはセルの形状は時間と共に 変化し， $R=45 R_{c}$ においてこの比が 1.8 と 2.6 の間の領域におちつつく（c）初期の比が $3,2.4$ 及び 2 の場合には モードの変化は起らない,などのことがわかった。 